\title{
Aeroallergens and asthma
}

\author{
MOIRA CHAN-YEUNG MB FRCPC, SANTIAGO QUIRCE MD PhD \\ Respiratory Division, Department of Medicine, Vancouver Hospital and \\ Health Sciences Centre, University of British Columbia, Vancouver, British Columbia
}

M ChAN-Yeung, S Quirce. Aeroallergens and asthma. Can Respir J 1994;1(4):248-256.

The main acroillergens in both the indoor and outdoor environment that have been implicated in the pathogenesis of allereice asthmit ale reviewed. Pollen and fungal spores are important outdor acroallergens that cause sensitization in atopic subjects, leading to rhinitis and asthma in a proportion of the sensitized subjects. Each pollen type displays a particular seasonal periodicity: tree pollen are prevalent in the late winler and spring, grass in the spring and summer and weed mainly in the fall. There are regional differences in the type of pollen grains in Canada. Although the pollen grains arc large. fragments less than $10 \mu m$ can reach the lower airwatys to cause asthma. Some fungal spores, such as Altomaria and cladesporium, have been implicated in asthmia. The full clinical impatet of fungi in asthma has yet (o) be clarified. Will the construction of homes that are tightly seatled to conserve heat and the use of wall to wall carpet. the type and concentration of indoor aeroallergens have become increasingly difierent from outdoors. House dust mite and pet allergens have now been shown to be important acroallergens that sensitize children in infancy and are risk fiketors for asthmat. Clinicians should recognize the importance of aleroallergens in asthma because avoidance and/or reduction ol exposure is an important part of the management besides drug therapy.

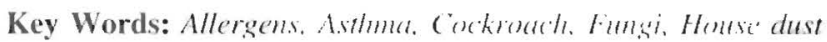
mites. IIypersensitivity: Pets. Pollen

\section{Les aéroallergènes et l'asthme}

RÉSUMÉ : Les principaux aéroallergènes présents dans l'environnement intérieur et extérieur et, impliqués dans la pathogenèse de l'asthme allergique, sont passés en revue. Les pollens et les spores des moisissures sont des aéroallergènes majeurs de l'environnement extérieur qui provoquent une sensibilisation chez des sujets atopiques puis, de la thinite et de l'asthme chez un pourcentage des sujets sensibilisés. Chaque type de pollen démontre une périodicité saisonnière spécifique. Les pollens d'arbres prévalent vers la fin de l'hiver et au printemps, ceux du gazon au printemps et en été et, ceux des mauvaises herbes surtout en automne. Au Canada, on a observé des différences régionales dans le type de grains de pollens. Bien que les grains de pollens soient gros, des fragments de moins de $10 \mu \mathrm{m}$ peuvent atteindre les voies respiratoires inférieures et causer de l'asthme. Certaines spores de moisissures telles que Alternaria et Cladosporium ont été impliquées dans l'asthme. L'importance de l'impact clinique des moisissures dans l'asthme reste à clarifier. La construction de maisons hermétiques pour conserver la chaleur et la pore de mexpletles font que le type et la densité des aéroallergènes de l'environnement intérieur se distinguent de plus en plus de ceux identifiés à l'extéricur. Les acariens de la poussière et les allergènes de source animale sont maintenant identiliés comme des aéroallergènes majeurs qui sensibilisent les enfants dans l'enfance et sont des facteurs de risque pour l'asthme. Les cliniciens devraient reconnaître l'importance des aéroallergènes dans I'asthme puisque leur éviction cy/ou une rédıction du contact à ces substances jouent un rôle importint diuns lit prise en charge en plus du traitement médicamentcux. 
A STHMA IS I MULTH:MC'IORIAL IDISEASE, DETERMINED BY a combination of genetic and environmental lactors. While scientists anc still strugglingr to discover an asthma gene, a great deal ol information hats becomc atvaliable in relation to environmental lackors in asthmal.

Environmental factors can be divided into two groups: air pollutants and acroallergens. Both groups are present indoors and outdoors. For many aeroallergens, indoor levels are dopendent on outdoor levels. However, with the construction of homes that are tightly sealed toconserve heal during the patst decade and the use of wall to wall carpeting. the type and concentralion of indoor acroallergens have become increasingly different from those outdoors. $A$ s most people spend more than $90 \%$ of time indoors, the indoor cnviromment deserves more attention and study than it used 10.

This is a review of the main acroallergens in both the outdoor and inforor environment that have been implicated in the pathogencsis of atlergic asthma. Occupational exposure will not be considered. The mechanisms by which these aeroallergens cause airways inflammation and bronchial hyperresponsiveness as well as the allergic evaluation of the asthmatic patient are beyond the seope of this revicw.

\section{OUTDOOR AEROALLERGENS}

Pollen and fungal spores are the most important outdor aeroallergens that catse sensitization in atopic subjects.

\section{Pollen}

The pollen grain is the specialized structure hat houses the sperm or male gameles of flowering plants. It comprises two to four cells combined as a unit. The pollen grain typically is composed of approximately $20 \%$ protein, $37 \%$ carbohydrate, $4 \%$ lipid and $3 \%$ minerals. Pollen is formed within the anther, which is an elongate structure containing the pollen sacs. Pollen grains are transferred to the female reproductive body mainly by wind or vector insects. Only 30 out of more than 300 families of flowering plants show adaptations for pollen dispersal in air currents and are termed anemophilous. Wind transported pollen tend to be between 10 and $40 \mu \mathrm{m}$ in size, dry, round and with little surface ornamentation. The germinal apertures are a major feature of pollen morphology. Families in which most of the genera are wind-pollinated, and of allergologic interest, include: Gramineae (grasses), Betulaceac (birches), Fagaceae (beeches, oaks), Cupressiaceae (junipers. cedars), Salicaceae (poplars), Ulmaceae (elms), Chonopoditceae (docks) and Urticaceae (nettles). Among several families that are predominantly pollinated by animal vectors, some genera are wind-pollinated, for example, the ragweed, Ambrosia, in the Compositae and the ash, Fraxinus, in the Olcaccac (I).

Pollen constitute a small part of the aeroplanklon or ait spora present in the anmosphere, since most frequent particles of biological origin are microorganisms, especially the spores of fungi. However, tree, grass and weed pollen are also common airborne particles in the ambient atmosphere. Polken grains may tavel long distances before they are deposited. The pollen season in temperate climates is restricted to the warmer months of the year from late winter through autumen. As the llowering season progresses, different pollen are present in the atmosphere, so that cach type displays a particular seasonal periodicity.

In most temperate climates, the seasonal progression first involves tree pollen in late winter and carly spring. The pollen of birch, alder, hazel, oak, ash and clm lead the pollen calendar. The grass season begins in late spring and early summer. This is followed closely by various weeds, for ex ample nette, dock, sorel and plantatin, In North America, various amaranths and ragweeds begin to pollinate in the autumn (1). Both the time of commencement and duration of the pollen season have been shown to be dependent on eleva tion above sea level and geographic position. However, marked differences in onset of the pollen season and in the total amount of pollen released occur from year to year.

Atmospheric conditions such as temperature, relative humidity and wind speed and turbulence affect the release and dispersal of pollen grains. Epidemics of asthma have been associated with thunderstorms. On two consecutive occasions after thunderstorms in Melbourne, Australia there were 10 -fold increases in cases of asthma admissions (2) which was thought to be due to the release of micronic particles from grass pollen after substantial rainlatl.

Pollen have been implicalled in several allergic diseases, including allergic thinitis, bronchial asthma, as well as in several eye and skin disorders $(3,4)$. In fact, atopic diseases, particularly those induced by pollen allergens (rhinoconjunctivitis and asthma), have become more common during the past two decardes (5.6). Pollen grains are usually too large to penetrate the lower airways. However, allergenic activity has been lound in auborne fragments smaller than pollen for both ragweed (7) and ryegrass (8). In the case of ryegrass, it has been shown that pollen grains are ruptured in rainwater by osmotic shock, each grain releasing about 700 starch granules into the atmosphere. These granules are small enough to enter the airways (less than $3 \mu \mathrm{m}$ in diameter) and tests in asthmatics have shown that suspensions of these granules provoked immunoglobulin (Ig) E-mediated responses (8).

An increase in nonallergic bronchial hyperresponsivencss to methacholine has been demonstrated in pollen-sensitive asthmatic subjects during and aller the pollen season (9). The number of pollen grains required to clicit symptoms is unclear but studies indicate that the number is greater at the beginning than at the end of the season. an effect known as priming. Empirical data suggest that the threshold concentra lion lies between 10 and 50 grains $/ \mathrm{m}^{3}$.

A characteristic feature of pollen semsitivity is its scaisonat pattern of occurrence, usually at the lime when the pollen count is highest in the atmosphere. Because the diagnosis of pollen sensitivity is partly dependent on patients' symptoms during the pollen season, physicians need to know the season and the amount of pollen from allergenic plants.

Different devices are used lor acrobiological sampling such as Durham greased slide (gravitational), the rotating impaction sampler (impaction) or the volumetric Burkard spore trap (suction) (4). Chatterjee and Hargreave (10) stud- 
TABLE 1

Flowering period and relative abundance of relevant allergenic plants in Canada

\begin{tabular}{|c|c|c|c|c|c|c|c|c|c|c|c|c|c|c|c|}
\hline & $\begin{array}{l}\text { Flowering } \\
\text { period }\end{array}$ & BC & Alta & Sask & MB & $\begin{array}{l}\text { N } \\
\text { Ont }\end{array}$ & $\begin{array}{l}\text { S } \\
\text { Ont }\end{array}$ & $\begin{array}{l}\text { N } \\
\text { Que }\end{array}$ & $\begin{array}{l}\text { S } \\
\text { Que }\end{array}$ & NB & PEI & NS & Nffld & Yukon & NWT \\
\hline \multicolumn{16}{|l|}{ Grasses } \\
\hline $\begin{array}{l}\text { Grass, Kentucky blue } \\
\text { (Poa pratensis) }\end{array}$ & May-July & ++++ & +++ & +++ & +++ & +++ & ++++ & +++ & ++++ & +++ & ++++ & ++++ & +++ & + & + \\
\hline $\begin{array}{l}\text { Grass, orchard } \\
\text { (Dactylis glomerata) }\end{array}$ & June-July & +++ & + & + & + & + & ++++ & + & ++++ & +++ & + & +++ & + & + & \\
\hline $\begin{array}{l}\text { Grass, Timothy } \\
\text { (Phleum pratense) }\end{array}$ & June-July & +++ & +++ & +++ & +++ & +++ & ++++ & +++ & ++++ & +++ & +++ & +++ & +++ & + & + \\
\hline \multicolumn{16}{|l|}{ Weeds } \\
\hline $\begin{array}{l}\text { Ragweed common } \\
\text { (Ambrosia artemisiifolia) }\end{array}$ & July-Sept & + & + & + & + & + & ++++ & + & +++++ & + & + & + & + & & + \\
\hline $\begin{array}{l}\text { Lambs' quarters } \\
\text { (Chenopodium album) }\end{array}$ & July-Sept & ++++ & +++ & +++ & ++++ & +++ & ++++ & +++ & ++++ & +++ & +++ & +++ & +++ & + & + \\
\hline $\begin{array}{l}\text { Mugwort } \\
\text { (Artemisia vulgaris) }\end{array}$ & Aug-Sept & + & + & + & + & + & + & + & + & + & + & + & + & & \\
\hline $\begin{array}{l}\text { Pigweed, redroot } \\
\text { (Amaranthus retroflexus) }\end{array}$ & July-Aug & +++ & + & + & + & + & +++ & + & +++ & +++ & +++ & + & & & \\
\hline $\begin{array}{l}\text { Plantain, English } \\
\text { (Plantago lanceolata) }\end{array}$ & June-Oct & ++++ & & & & + & +++ & + & +++ & + & + & ++++ & +++ & & \\
\hline $\begin{array}{l}\text { Russian thistle } \\
\text { (Salsola pestifer) }\end{array}$ & July-Sept & +++ & ++++ & ++++ & ++++ & + & + & + & + & + & + & + & & & \\
\hline $\begin{array}{l}\text { Sorrel, sheep } \\
\text { (Rumex acetosella) }\end{array}$ & June-Aug & +++ & +++ & + & + & +++ & +++ & +++ & +++ & +++ & + & +++ & +++ & + & \\
\hline \multicolumn{16}{|l|}{ Trees } \\
\hline $\begin{array}{l}\text { Eim, white } \\
\text { (Uimus americana) }\end{array}$ & Apr-May & & & + & + & + & +++ & + & +++ & +++ & + & +++ & + & & \\
\hline $\begin{array}{l}\text { Oak, red } \\
\text { (Quercus rubra) }\end{array}$ & May-June & & & & & + & +++ & + & +++ & +++ & + & +++ & & & \\
\hline $\begin{array}{l}\text { Birch, white } \\
\text { (Betula papyrifera) }\end{array}$ & Apr-May & ++++ & +++ & + & +++ & ++++ & ++++ & ++++ & ++++ & ++++ & +++ & ++++ & ++++ & +++ & +++ \\
\hline $\begin{array}{l}\text { Ash, white } \\
\text { (Fraxinus americana) }\end{array}$ & May-June & & & & & + & +++ & + & +++ & +++ & +++ & +++ & & & \\
\hline $\begin{array}{l}\text { Juniper, common } \\
\text { (Juniperus communis) }\end{array}$ & Apr-May & +++ & +++ & + & + & +++ & +++ & +++ & +++ & +++ & + & +++ & +++ & & \\
\hline $\begin{array}{l}\text { Maple, Manitoba } \\
\text { (Acer negundo) }\end{array}$ & May-June & + & + & +++ & ++++ & + & +++ & & + & & & & & & \\
\hline
\end{tabular}

Data modified from reference 11

ied the atmospheric pollen and fungal spores in Hamilton, Ontario using an automatic volumetric spore trap. Immunological methods of identifying and quantifying airborne allergens have been developed in recent years. Table I shows the flowering period and the relative amount of polien from the most common allergenic plants in Canada (modified from reference 11). Note the important regional geographical differences, particularly for weed and tree pollens. The above information is very useful to pollen-sensitive patients when they plan trips and in the prevention of severe allergic symptoms by appropriate medication or other measures (12).

Grass pollen sensitivity is the most common cause of allergic disease worldwide (4). This is due to the wide distribution of wind-pollinated grasses. The allergens from ryegrass (Lolium perenne) and timothy (Phleum protense) have been most extensively studied and some have been isolated. The original studics carried out by Marsh (1.3) and Matthiesen and Lowenstein (I4) showed that the pollen from these grasses contained several allergens. In the past, four of the most important allergens in ryegrass were designated groups I to IV, and the main allergens in timothy were termed groups V, VI and VII. Recently, allergens from grass pollen have been isolated and characterized and they are now designated according to the new allergen nomenclature. These individual allergens include Lol $p$ I-IV from $L$ perenhe, $P h t p$ V from Ppratense, Cynd I from Cynodon dactylon, Dac $g$ I and V from Dactylis glomerata, and Poa $p$ I from Poa pratensis: Allergens from diflerent grass species show a high degree of cross-reactivity (4).

The ragweed tribe is the most important cause of allergic rhinitis and pollen asthma in North America (4). Short ragweed pollen (Ambrosiat artemisiffolia) contains 22 allergens (15), and the two major allergens, Amb a I (former antigen E) and $A m b$ a II, have been isolated. Other allergens have been purified from additional weeds, such as Sal p I from Salsola pestifer (Russian thistle) (16) and Par $j$ I from Parietaria judaica pollen (17). Members of the two closely related Chenopodiaceae (lamb's quarters, Russian thistle) and 
Amaranthaccale (redrool pigweed) lamilies show varying degrees of cross-reactivity.

The allergenic fractions of trees have not been studied as well as ragweed or gatsses. A few major allergens have been isolated, including Bet $v$ I from Betula vulgaris (birch) (I8). and Cor a I from Corvlus avellana (hazel). The latter only differ in two residues from the matjor allergen of birch (19). Jun s I has been isolated from Imipertss sabinoides (mountain cedar) (20), and Ole $\mathrm{I}$ from Olea éuropaca (olive) (21). which is shared by other species of the Oleatceac fitnily (22).

\section{Fungi or moulds}

Fungi or moulds are a heterogeneous group of nonphotosynthetic organisms that are grouped in the plant kingdom because of the presence of a cell wall. They are 80 to $90 \%$ polysaccharide in composition (23). Fungi grow best at relative humidity of 75 to $95 \%$, but others like Aspergillus can grow in lower humidity because they can extract water from the atmosphere.

The spores of fungi range between 3 to $200 \mu \mathrm{mm}$, with the majority at around $10 \mu \mathrm{m}$. However, it has been pointed out by Licorish and co-workers (24) that some spores are quite small, such as Penicillium (less than $5 \mu \mathrm{m}$ ) and the young spores of Alternaria (less than $10 \mu \mathrm{m}$ ). Moreover, the snowshoeshaped Alternaria spore has different aerodynamic properties that keep it from having an impact in the upper airways.

There are four major groups of fingi: (a) Phyconycetes Rhizopus, Mucor - sugar and bread moulds; (b) Asconycetes (sac fungi) - black moulds and blue moulds, yeast; (c) Basidiomycetes (club fungi) - rusts, smuts, mushrooms. puffballs; (d) Deuteronycetes (fungi imperfecti) Cladosporinm. Alemaria, Aspergillus. Helminthosporimm. Penicillium. The last group consists of most of the fungi allergenic for humatns. There are studics to indicate that the basidiospores maty also be important particularly in the southern United States (25). Many fungal spores are virtually always present over large land masses. They are present in higher concentraltion than polien, sometimes 40 times higher. The particular species and concentration in the air at any given time are dependent on temperature, rainfall, prevailing winds, seasonal climatological factors, circadian patterns of sunlight and darkness, availability of substrates, and the degree of both substrate and atmospheric moisture (23). For example, the dispersal of basidiospores and their growth are affected by atmospheric moisture; the spores are propelled into the atmosphere during periods of rainlall and dampness. Circadian rhythms in humidity and temperature interact to foster nocturnal or diumal increases in certain basidiospore concentrations (26). Cladosporimu and Alternarica are blown free by wind, and these spores increase in concentration with diminishing humidity and increasing arrlow. Thus, these species are often abundant during mid-day periods with maximal sunlight.

Most of the fungal sprores found indoors are from the outside. However, high levels of fungi are present inside damp houses particularly on garbage containers, food storage areas, wallpaper, damp batsement, shower curtains and win- dow mouldings. New buildings are being constructed tightly to avoid air leaks in order to save heitting cost and, as a result. indoor humidity increases. There is at possibility that occiasionally buildings or homes may become sufficiently contaminated with mould to caluse asthma (23).

The role of fungi in asthma is not fully understood. This is due to many factors: the choice and method of preparing fungal extracts for skin testing and bronchoprovocation testing vary markedly among investigators; the quality and potency of mould allergenic extracts have often been poor: relatively few fungi have been studied in detail; a single, brict well-tkfined 'mould season' usually does not occur (23). In addition, there are difficulties with identification of mould allergens (27). Many fungi have very specific growth requirements that prevent culture in the laboratory. The spores are not discrete in morphology, while culture methods may bo nuiskalding because some spores maty not germinate. Moulds may be airborne in amorphous particles and enumeration of spores may underestimate the total anount of antigen in the air. Thus, identification of fungal aeroallergens may require a combination of methods including microseopic counts. culture and immunochemical assiy.

During the past 15 years, several studies have demonstrated the relationship between increase in asthma severity and high fungal spore counts. Salviggio and Aukrust (25) showed that an increased incidence of asthnat admissions in New Orleans, during the months of September to November. was associated with very high outdoor total spore counts. Hasnain et al (28) also showed similar findings in New Zealand. In the Netherlands. Beaumont et al (29) showed a positive correlation between decreased peak flow rates with high outdoor spore levels. In 24 patients with asthmat who had positive skin and bronchial reactions to Cladesporium, Malling (30) found a positive correlation between the weekly symptom scores, medication scores, total scores and the Cladosporium sporc counts. Lopez and coworkers (31) studied cight asthmatic patients who had positive shin tests to extracts of basidiospores and asthmaties with negative skin test. Those with positive skin test had positive inhalation chatlenge to extract of basidiospores. O'Hollaren and colleagues (32) reported that exposure to Alternaric in the summer or early fall maly be responsible for the severe attack of asthma in I 1 patients, fatal in two cases, in the upper midwest of the United States. The study by Licorish et al (24) provided confirmation that inhalation of Alternatia or Penicillium spores can cause asthma in mould-sensitive patients.

The level of fungal spores in the atmosphere correlates with the level of $\lg$ E synthesis. Agarwal et at (3.3) found that the level of Attermartu spore counts correlated with the ability of the extract to induce positive skin test: similarly, the immunochemical atetivity of the allerenens paralleled the mean symptom scores. Roby and Sneller (34) studied 1.37 patients with allergic rhinitis or asthma and performed spore counts indoors and outdoors. The prevalence of positive skin test to different fungal extracts correlated with the levels of the dilferent indoor spore counts.

Thus. there is good evidenec that allergy to fungi play a 


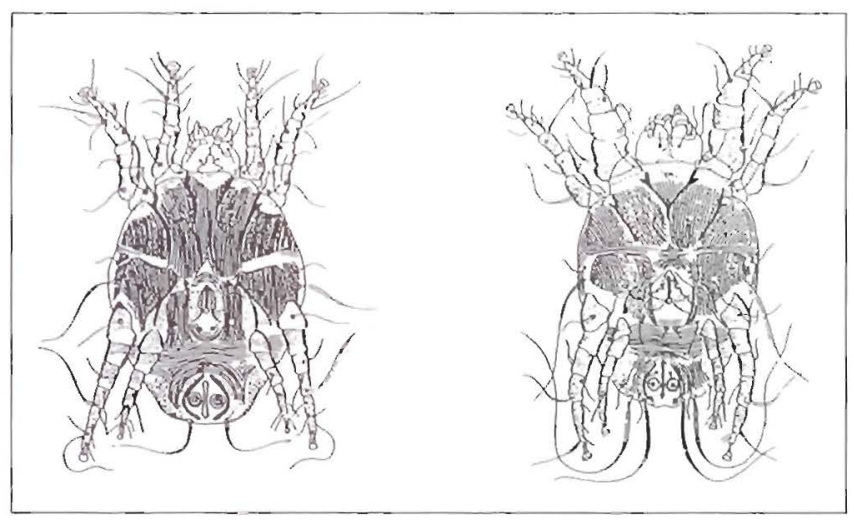

Figure 1) Male speriments of the house dust mites Dermatophagoides pleronyssinus (left) and Dematophlagesictes farinae (right). (Roproduced with permisiom fiom s.3)

role in asthmial. The full clinical impact of airborne fungi on asthma will not be known until there is standardization of allergens from a wide range of lungal species (35).

\section{INDOOR AEROALLERGENS}

The indoor aeroallergens of importance are house dust mites, pets and cockroiches. In parts of the United Kingdom, Australia, New Zealand and the United States, house dust mites are the most important allergen, with 70) $1080 \%$ of asthmaties reacting on skin test to the mite allergens (36). Pets are the second most common important cause of allergy in developed countries, and up to $40 \%$ of asthmatic children ate sensitized to allergens of cats and/or dogs (37). In recent years, cockroaches have become important allergens responsible for symptoms in asthmatics in inner cities of the United States (38).

\section{House dust mites}

Dust hats been recognized als a triggering factor for asthma for many centuries. In 1964. Voorhorst and co-workcrs (39) first suggested that the most important source of house dust allergen wils mites of the genus Dermaterphagoides. Miyamoto and associates in Japan $(40,41)$ expanded the work and showed that the polency of house dust allergen is related to the number of mites in the dust. Skin tests, radioallergosorbent test and bronchoprovocation tests performed with extracts from pure cultures of mites correlated well with results obtained using house dust extracts. The equivalemt potency of mite extracts was 1010100 times that of dust.

Mites are sightless, eight-legged, ahoul 1/3 mm long. and are members of the order Acaridac (close relatives of ticks and spiders). Species of known imporlance are Dermatophagoides pteronyssinus, D) farman (Figure I) and Eurostyphus maynei. The main determinants for survival are high humidity. moderate temperitures and all adcequate food source that alre provided amply hy human skin scales. $D$ pteronysints and $E$ maynei are the most common European species, while $D$ farinae, which is more resistant to desiccation, is more common in North America (42). The key deter- minan for excess mite growth appears to be an indoor relative humiclity of $60 \%$ at $21^{\circ} \mathrm{C}$ and $75 \%$ at $16^{\circ} \mathrm{C}$. When the relative humidity falls below 40 to $50 \%$, mites are unable to survive more than 11 days at temperatures above $25^{\circ} \mathrm{C}$, beciatuse increalsed transpiration of water leads to dehyctration (4.3).

In the United States, house dust miles muliply in the months of July and August when humidity is highest. Mite allergens are found in dust samples collected from mattresses and bedroom floors from Iuly w December as these allergens are found mostly in licess of miles, which persist long after the mites are gone (4t).

There are two major groups of mitc allergens. Group I allergens (Der $p$ l, Der $f$ I) are protolylic enzymes secreted from the digestive tract and lound in high concentrations in fical pellets (45). Mites are coprophagic, ie, they re-ingest fecal pellets, and it is possible that the presence of these enzymes allows a more extensive digestion to occur after defecation. Group II (Der $p$ II, Der $f$ II) allergens are found both in fecal pellets and mite bodies.

There are three methods of estimating exposure to milcs: mite counts, assay of mite allergens and measurement of guanine (36). The most widely used assays for measuring group I allergens are the enzyme-linked immunosorbent assay (ELISA) method with species-specific monoclonal antibodies to bind the allergen, and labelled group-specific antibodies for detection (46). Counting of house dust mites is tedious and may not give the mite allergen content in the dust. The quantitative assay for guanine is not commercially available (36). Theoretically, measurements of airborne allergen should be more representative of exposure than assays on settled dust. However, there have been few data demonstrating a relationship between airborne dust and sensitization and respiratory symptoms. In general, levels of airborne allergens are low and undetectable in the absence of dust disturbance. After disturbance, concentrations of allergens fall rapidly, because the particles are large (47).

There are many studies providing evidence that the house dust mite is an important cause of asthma in many parts of the world. First, there is an ecological relationship between the levels of house dust mites and the prevalence of asthma. A low prevalence of asthma has been found in areas of low mitc exposure such as in high altitudes where the absolute humidity both indoors and outdoors is low (48). These areas tend to be climatically inhospitable and sparsely inhabited. Reports from Papua New Guinea described how contact with western civilization was followed by an increase in the prevalence of asthma. An explanation for this has been the introduction of blankets infested with mites to this native population, leading to sensitization and subsequent development of asthma (49). In areas with high mite exposure such as in the Unitcd Kingdom, coastal areas of Australia, New Zealand, Japan and Brazil, 'all' atopic children can become sensitized (43).

Second, there is a dose-response rclationship between the level of mite allergen exposure and the risk of sensitization. In the United Kingdom, where mite allergen levels are in general high, approximately $80 \%$ of asthmatic children were 
sensitized to house dust mites (4.3). The prevalence of positive skin test reaction to mite allergens was about $45 \%$ in two Canadian cities where the mite allergen levels were found to be relatively low (50). The risk of asthma was seven times higher in German children if their current exposure to De' $p$ I wals greater than $2 \mu \mathrm{g} / \mathrm{g}$ of dust, and $1 \mathrm{I}$ times higher for exposure above $10 \mu \mathrm{g} / \mathrm{g}$ than those with less than $2 \mu \mathrm{g} / \mathrm{g}$ (51).

Third, reduction of exposure to house dust mitcs resulted in improvenent in asthma in subjects allergic to them. Placeing childiren in at sinatorium al high altitude. where mite levels are kow. hatd been a tridditional treatment of severe asthmil and ustally resulted in improvenent of their symptoms (52). Adult asthmatics allergic to house dust mites improved considerably in an allergen-fiee environment in a hospital although it took two to three months for improvement to occur (53). The use of acaricides and enclosure of mattresses have been shown 10 reduce the mite allergen level and severity of asthma $(54.55)$.

The most convincing evidence thall house dust mite is important in asthma comes from two prospective sludies. Sporik and colleagues (56) conducted a longitudinal study of children at high risk for ckeveloping asthmal and allergies at birth, and followed them for 11 years. They found that children whose homes had high mite allergen levels during the first year of life were at a much higher rish for developing asthma than those with low levels. Arshad and co-workers (57) conducted a randomized clinical trial on infants at high risk for developing allergy and asthma. The prophylactic group had measures to reduce house dust mite exposure and dietary restriction. The control group hadd no treatment. At the end of 12 months, those in the eontrol group had four times the risk of developing asthmal as those in the prophylactic group.

In at study of envirommental risk factors in patients with asthmal in Vancouver and Winnipeg, a positive correlation was found between mite allergen levels in the homes of patients and the degree of skin test reactivity to mites $(50)$. There was also an inverse relationship between the levels of mite allergens and the levels of lung function in children with asthma, indicating that nite allergen levels are of clinical relevance.

There are now effective means of reducing mite allergens such as the use of a dust cover for mattresses and pillows, the use of hot water for washing atl beddings, and the removal of carpets particularly in the bedroom. The availability of aciricides adds another armament to the regimen.

\section{Pets}

Hypersensitivity to pet allergens is extremely common. Surveys have shown that $51015 \%$ of the general population and 40 to $70 \%$ of patients with asthma have positive skin test reactions to cal and/or dog dander (37,58-60). Close human contact accounts for the high prevalence of pet sensitivity in Western societies. It has been estimated that either cals or dogs are found in over $50 \%$ of homes in many countries (61). Laboratory animals (mouse, ralt, guinea-pig, rabbit) and latm animals (horse, cow) can also give rise to allergic sensitization in exposed persons, mathly in an occupational context (62). These mammals secrece proteins that maty ated as potential aeroallergens when they are inhated. Several of these allergens have been identified and a few of them characterized.

Cats alre the most prevalent cause of pet allergy (03). The sources of the allergens in cats are the pelt, dander, salivat, urine and serum (62). Several molecules in cat extracts have been shown to be allergenic and the relative concentration of these allergens varies depending on the source of extract. The most important allergen from a clinical point of view is Fel d I (64). Most of the IgE antibodies cliciled in catt-sensitive patients are directed against this allergen. Fel $d \mathrm{I}$ is found in salivary glands. hair follicles, saliva and lacrinal fluid (65). The existence of $\mathrm{B}$ and $\mathrm{T}$ cell epitopes in the Fel $\mathrm{II}$ molecule has been demonstrated (66). The most importint allergen derived from dogs is $\operatorname{Can} f \mathrm{I}$ and is present in high concentrations in dog hair, dander and saliva (67). This allergen accounts for alt least half of the allergenic aktivity in dog hair and dander extract (67).

The development of monoclonal antibody-based assays has made it possible to determine the level of environmental exposure to $\mathrm{Fo}^{\prime} \mathrm{d}$ / I (68) and (an f I (6) ) and to study the relationship between exposure and development of sensitization and exacerbation of symptoms. Fxposure to a level of Fel $d \mathrm{I}$ in the house greater than $8 \mathrm{~g} g / \mathrm{g}$ of dust in a sensitized subject is a risk factor for acute asthma cpisodes leading to emergency room visits (70)). It is likely that clinically relevant threshold limits for pet allergen cxposure will be proposed within the next few years.

Throughout the home Fel $\mathrm{d}$ hals been found in dust from floors, mattresses and soft furnishings, on walls and in the air (61). The wide distribution of the allergen is due to a significant proportion of $\mathrm{Fel}$ d I present on particles smaller than 2.5 $\mu \mathrm{m}$ in diameter, which readily become airborne and remain in the air for long periods even in undisturbed conditions (71). Interestingly, measurable anmounts of $\mathrm{F} d \mathrm{~d} l \mathrm{l}$ have been found in almost every home investigatled, including those without cats in residence, and in public buildings $(72,73)$. It has been suggested that Fol d I is catriced into cal-free buildings on the clohing of people exposed to calts (73). Studies in Scandinatvian schools have shown that while mite allergen levels were low in the classrooms, at high level of both cat and dog allergen was found on either smooth or carpeted floors, with approximalely 11 times more on the carpeted floors (74). It wals estimited that $30 \mathrm{ng} F \mathrm{fl} / \mathrm{l} / \mathrm{m}^{3}$ was brought into the classrom every diay, and this is highly significant for chitdren with call sensitivity. Another recent study from Siweden showed that levels of both fol $d \mathbf{I}$ and Can fI I were much higher on chairs thatn on floors, suggesting that allergens were brought in by students and teachers on their clothing. These levels were probahly high enough to sensitize children and to induce asthma in most children who atre allergic to cats or $\operatorname{dogs}(75)$.

In at study of paticnts with asthnia in Vancouver and Winnipeg, levels of $\mathrm{Fel} d \mathrm{I}$ in dust simples collected from 
mattresses and bedroom libors were madsured. Cal allergen was present in every home, even in those without a call (76). Fold I levels were highest in homes of patients with cats, and rather high tevels were also found in homes of patients without at cat but who hatd visited others with cats. The lowest levels were found in homes of patients without a cat and where the occupants did not visit others with such a pet. Cat atlergen levels were highest during the winter and spring and lowest in summer and atumn in Winnipeg, probably due to the tighter instlation of the homes during winter months. Such seasonal variation wats not found in Vancouver. There was no relationship between sensitization 10 cats and previous of current cat ownership. The findings are in keping with recent studies showing that Fel d I is a ubiquitous atlergen. It is likely that the cat allergen was brought into homes on clothing of occupants when they visited homes with calts.

Once a diagnosis of pet allergy hat been made, several therapeutic options are available. The most effective method is to remove the animal complelely, although this maly not be possible in all situations. Even atter removal of the pet, it maty take several months to reduce the allergen content within the home. Aggressive cleaning meatsures should be instituted ats rapidly as possible. If the symptoms are mild and the pationt or the family refuses to give up the pet. some preventive measures should be taken to limit exposure. The allergen content maly be reduced by limiting the pet's aceess to the home. removing carpets and upholstered furniture, increasing ventilation, and by using room air cleaners, particularly those with high efficiency particulate air or electrostatic filters. There is some evidence that washing cats weckly will reduce the amount ol $\mathrm{Fel} d \mathrm{I}$ in the home (77). Nevertheless, the effectiveness of these measures on allergen levels and patients symptoms remains to be defined. Further, even il at patient can avoid animal exposure at home, pets are so common that some degree of exposure outside the home is inevilable (78).

\section{Cockroaches}

Cockroaches have been described as allergens based on skin test datat on allergic subjects (79). Kang and associates (80) extended the work to include radioallergosorbent and bronchoprovocation studies with cockroach extract. Asthmatics with positive skin tests to cockroach extracts had

\section{REFERENCES}

1. Knox RB. Aerobiology. In: Knox RB. ed. Pollen and Allergy. London: Edward Arnokl L.h. 1979).

2. Bellomo R, Giglioni P, Treolar A, el al. Two consecutive thunderstorm associated epidenics of asthmat in the city of Melbourte. Med J Aust 1992:150:834-7.

3. Solomon WR, Mathews KP. Aerobiology and inhalant allergens. In: Middleton E Jr, Reed CE, Ellis LF, Adhinson NI: Ir. Yunginger JW, eds. Allergy: Principles and Pratclice. 3rd edn. Si Luuis: CV Mosby Co, 1988:312-72.

4. Gutman A A. Bush RK. Allergens and other factors important in alopic disease. In: Palterson R, Grammer I C. Grecberger PA, Zeiss CR, eds. Allergic Diseases: Diagnusis and Management, the edn. Philadelphial JB Lippincoll Co. higher total serum IgE levels than their allergic counterparts with negative skin tests. Bronchoprovocation test indued transient peripheral eosinophilia in those who reacted posilively. Immunophoretic studies hatve shown that roach atlergens were mostly found in the whole body and cast skin fractions. Feces and egg casings were less allergenic (81). Hypersensitivity to cockroach allergens is particularly important in inner city asthmatics (38).

\section{SUMMARY AND CLINICAL RELEVANCE}

The relative risks of sensitivity to virious outdoor and indoor aeroallergens in the development of childhood asthma were investigated by Sears and colleagues (82) in a longitudinal study of a birth cohort of New Zealand children up to the age of 13 years. Of the 714 children skin-tested, $45.8 \%$ were sensitive $t 0$ at least one of 14 allergens, the most common responses being to rye grass pollen $(32.5 \%)$, house dust mite (30.1\%) and call dander $(13.5 \%)$. Sensitivity to house dust mite, cat dander and Aspergillus were independent risk factors associated with the development of asthma, while grass sensitivity and sensitivity to at number of outdorer acoallergens were not. Gelber and coworkers (70) conducted a catse-controlled study on adult pationts ( 137 in each group) presenting $t o$ an emergency room over a period of one year. They found that $38 \%$ of the asthmatics, but only $8 \%$ of the controls, were allergic to one of the three indoor allergens and had high levels of the relevant allergen in their houses. They conciuded that the risk for asthma related to sensitization to indoor atlergens applics to many adults with acute asthma. These two studies showed that indoor ateroallergens are inportant determinants for asthma in children and in adults.

Exposure to indoor houschold allergens is a leading canse of perennial IgE-mediated asthma and rhinitis. Ongoing daily exposure to allergens kads to perpetuation of the inflammatory process in the airway that is the likely catuse for the persistence of symptoms and airwaty hyperesponsiveness. Clinicians should recogni/e the importance of indoor acroaflergens in asthma because avoidance and/or reduction of expostre is an important part of the management besides pharmacological management. Finally, clinicians should atso be aware that high levels of per allergens ma be found in schools and other public places and may account for the persistence of symptoms despite stringent measures of avoidance at homc.

[) () 3:9.9-1.58.

5. Turkeltaut PC. Cieren PJ. Prevalence of upper and lower respiratory conditions in the US population by social and environmental lactors. Data from the second National Health and Nutrition Examination Surve'y 1976101980 (NHANES II). Ann Allergy 1991;67:147-54.

6. Fleming DM, Crombie DL. Prevalence of asthma and haty fever in England and Wales. BMJ $1987 ; 294: 270-83$.

7. Busse WW, Reed CE, Hoehne JH. Where is the allergic reaction in ragweed asthma? II. Demonstration ol ragweed antigen in airborne particles smatler than pollen. J Allergy Clin Inumunol 1972;50:289-93.

8. Suphioglu C, Singh MB, Tayfor P. Ct al. Mechanism of grass-pollen-induced asthma. Lancet $1992 ; 339: 569-72$. 
9. Prieto L, Berto JM, Lopez M, Peris A. Modifications of PC20 and maximal degree of airway narrowing 10 methacholine after pollen season in pollen sensitive asthmatic subjects. Clin Exp Allergy 1993;23:172-8.

10. Chatterjee J, Hargreave FE. Atmospheric pollen and fungal spores in Hamilton 1972 estimated by the Hirst automatic volumetric spore trap. Can Med Assoc J 1974:1 10:659-61.

11. Wight P, Basset IJ, Crompton CW, Parmelee JA. In: An Allas of Airborne Pollen Grains and Common Fungus Spores of Canada. Ottawa: Canada Department of Agriculture. Research Branch, 1978.

12. D'Amato G, Spieska FThM. Allergenic pollen in Europé Grana 1990;30:67-70.

13. Marsh D. Allergens and the genetics of allergy. In: Sela M, ed. The Antigens, vol 3. New York: Academic Press, 1975:271

14. Matthiesen F, Lowenstein H. Gramineae allergens: Biochemistry. Horshohm: ALK Research, 190:1.

15. King TP, Norman PS. Isolation sludies of allergens from ragweed pollen. Biochemistry $1962 ; 1: 709$

16. Shafiee A, Yunginger JW, Gleich GJ. Isolation and characterization of Russian thistle (Salsola pestifer) pollon allergens. J Allergy Clin Immunol 1981;67:472-81.

17. Cocchiara R, Locorstondo G, Parlato A, et al. Purification of Par j I, a major allergen from Parieturia juduca pollen. Int Arch Allergy Appl Immunol 1989;90:84-90.

18. Ipsen H, Løwenstein H. Isolation and immunchemical characterization of the major allergen of birch pollen (Be'tula verrucosa). J Allergy Clin Immunol 1983;72:150-9.

19. Elsayed S, Holen S, Dybendal T. Synthetic allergenic epitopes from the amino-terminal regions of the major allergens of hazel and birch pollen. Int Arch Allergy Appl Immunol 1989;89:410-6

20. Gross GN, Zimburean JM. Capra JD. Isolation and partial characterization of the allergen in mountain cedar pollen. Scand J Immunol 1978;8:437-41

21. Lombardero M, Quirce S, Duffort O, et al. Monoclonal antibodies against Olea europace major allergen: Allergenic activity of affinity-purified allergen and depleted extract and development of a radioimmunoassay for the quantitation of the allergen. J Allergy Clin Immunol 1992;89:884-94.

22. Obispo TM, Melero JA, Carpizo JA, Carreira J, Lombardero $\mathrm{M}$. The main allergen of Olea curopuca (Ole e I) is also present in other species of the Olcaceat family. Clin Exp Allergy 1993;23:311-6.

23. Lehrer S, Aukrust L, Salvaggio J. Respiratory allergy induced by fungi. Clin Chest Med 1983;4:23-39.

24. Licorish K, Novey H, Kozak P, Fairshter R. Wilson A. Role of Alternaria and Penicillium spores in the pathogenesis of asthma. J Allergy Clin Immunol 1985;76:819-25.

25. Salvaggio J, Aukrust I. Mold-induced asthma. J Allergy Clin Immunol 1981;68:327-46.

26. Paldy $\mathrm{S}$, Kramer $\mathrm{C}$, Clary $\mathrm{R}$. Diurnal periodicity in airborne fungi in an orchard. J Allergy Clin Immunol 1966;39:302.

27. Reed C. What we do and do not know about mold allergy and asthma. J Allergy Clin Immunol 1985;76:773-5.

28. Hasnain S, Wilson J, Newhook F. Fungal allergy and respiratory disease. NZ Med J 1985;98:342-6.

29. Beaumont F, Kauffman H, Sluiter H, de Vries K. Sequential sampling of fungal air spores inside and outside the homes of mould-sensitive, asthmatic patients: A search for a relationship to obstructive reactions. Ann Allergy 1983;55:740-6.

30. Malling HJ. Diagnosis and immunotherapy of mould allergy. Allergy 1986;41:342-50.

31. Lopez M, Salvaggio JB. Allergenicity and immunogenicity of Basidiomycetes. J Allergy Clin Immunol 1976;57:480-5.

32. $\mathrm{O}^{\prime}$ Hollaren M, Yunginger JW, Offord KP, et al. Exposure to itl aeroallergen as a possible precipitating factor in respiratory arrest in young patients with asthma. $\mathrm{N}$ Engl $\mathrm{J}$ Med 1991;324:359-63.

33. Agarwal MK, Yuninger J, Swanson $M$, cl al. An immunochemical mcthod to measure atmospheric allergens. J Allergy Clin Immunol 1981;68:194-200.

34. Rohy R, Sncller M. Incidence of fungal spores at the homes of allergic patients in an agricultural community. II Correlations of skin tests with mold frequency. Ann Allergy 1979;43:286.

35. Dhillon M. Current status of mold immunotherapy. Ann Allergy 1991;66:385-91.

36. Sporik R, Chapman MD, Platts-Mills TAF. Housc dust mite exposure as a cause of asthma. Clin Exp Allergy 1992;22:897-906.

37. Kjellman B, Petterson R. The problem of furred pets in childhood atopic disease. Allergy 1983;38:65-73.

38. Kang BC, Johnson J, Veres-Thorner C. Atopic profile of inner-city asthma with a comparative analysis on the cockroach-sensitive and ragweed sensitive subgroups. J Allergy Clin Immunol 1993;92:802-10.

39. Voorhorst R, Spieksma FThM, Varekamp H, Leupen MJ, Lyklema AW. The house dust mite (Dermatophagoides pteronyssinus) and the allergens it produces: identity with house dust allergen. J Allergy 1967;39:325.

40. Miyamoto T, Oshimi S, Ishizaki T. Antigenic relation between house dust and at dust mitc (Dermatophagoides farimate. Hughes, 1961) by a fractionation method. J Allergy 1969,44:282-91.

41. Miyamoto T, Oshima S, Ishizaki T. et al. Allergenic potency of different house dusts in relation to contained mites. Aun Allergy 1970;28:405-12.

42. Platts-Mills TAE, de Weck AL. Dust mite allergens and asthma - a world wide problem. J Allergy Clin Immunol 1989;83:416-27.

43. Platts-Mills TAE, Thomas WR, Aalberse RC, Vervloet I). Chapman MD. Dust mite allergens and asthma: Report of it second international workshop. J Allergy Clin Immunol 1992;89:1046-60.

44. Platts-Mills TAE, Hayden ML, Chapman MD, Wilkins SR. Seasonal variation in dust mite and grass-pollen allergens in dust from the houses of patients with asthma. J Allergy Clin Immunol 1987;97:781-91.

45. Tovey ER, Chapman MD, Platts-Mills TAE. Mite feces are a major source of house dust allergens. Nature 1981;289:592-3

46. Luczynska CM, Arruda LK, Platts-Mills TAE, Miller JD, Lopez M, Chapman MD. A two-site monoclonal antibody ELISA for the quantitation of the major Dermatophagoides spp. allergens, Der $p$ I and Derf I. J Immunol Methods 1989; 1 18:227-35.

47. Platts-Mills TAE, Heymann PW, Longbottom JL, Wilkins S, Airborne allergens asociated with asthma: Particle sizes carrying dust mite and rat allergens measured with a cascade impactor. J Allergy Clin Immunol 1986;77:850-7

48. Charpin D, Birnbaum J, Haddi E, et ill. Altitude and allergy to house dust mites. Am Rev Respir Dis I 199 I : [43:983-6.

49. Dowse GK, Turner KJ, Stewart GA, Alpers MP, Wookcoch AJ The association between Dermatophagoides mites and the increasing prevalence of asthma in village communities within the Papua New Guinea highlands. J Allergy Clin Immunol 1985;75:75-83.

50. Chan-Yeung M, Lam J, Ferguson A, et al. Relationship between mite allergen levels in the homes, skin test reactivity and asthma. Am Rev Respir Dis 1993;147: 14.59.

5I. Lau S, Falkenhorst G, Weber A, et al. High mite-allergen exposure increases the risk of sensitization in atopic children and young adults. J Allergy Clin Immunol 1989:84:718-25.

52. Vervolet D, Perrand JA, Razzouk H, et al. Altitude and house dust mites. J Allergy Clin Immunol 1982;69:290-6.

53. Platts-Mills TAE, Tovey ER, Mitchell EB, et al. Reduction of 
bronchial hyperriaclivily during prolonged allergen avoutancie Lancet 1982:1i:675-8.

54. Hhnert B. Latu-Schadendorf S. Weber A. Bucluner P, Schou C', Wahn (?. Reducing domestic exposure to dust mite allergen reduces bronchial hyperteictivity in sensitive chitdren with asthma. J Alkery ('lin Lmmunol 1992:90):135-8.

55. Colloff MJ, Aytes J. ('alrswell [: cl all. The control of allergens of dust mites and domestic pets: a position paper. Clin Fxp Allergy 1992;22(Suppl): 1-28.

56. Sporik R, Holgate ST, Platts-Mills TAL, Coswell JJ. Fxposuce to house-dust mite allergen (Der p l) and the development of asthna in childhorkl. N Engl J Med 1902:323:502-7.

57. Arshad SH, Matthews S, Gant C. Hide DW. Itllect of allergen avoidance on development of allergic disorders in infancy.

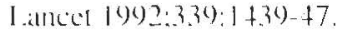

58. Croner $S$, Kjellman N-IM. Nattural history of bronchial asthmat in childhood - al prospective study from birth to I t yealls of ate Allergy 1092;77:150-7

59. Vanto T. Korvihko A. Dog hypersensitivity in asthmathic children. Acla Pacdiatl Scand 1983:72:571-5.

o(). Desjardins A, Benoit C. Gheso H, el al. Expostur to domestic animals and risk of immunologic sensitiotlon in subjects with asthma. J Allergy Clin Lmmunol 1943:(9):979-80.

61. Wanter JA. Fnvimmental altergen exposure in homes and

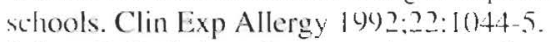

6.2. Schou $\mathrm{C}$. Defining allergens of mammalian orignin. Clin Ixp Allergy 1993;23:7-14.

63. Murray AS, Ferguson AC, Morrison BJ. The frequency and sensitivity of cat allergy vs dog allerey in atcpic chikdren. J Allergy Clin Inmumol 1983:72:145-9.

64. Ohman JL, Kendiall S. Lowell ICC. LgF. antibody a call atlergens in an allergic population. J Allergy ('lin lmunumol 1977:60:317-23.

65. Brown PR, L coltermann KM, Ohman JL. Distrihution of cat allergen I in cat tissues and fluids. Int Arch Alleryy Appl Immunol 1984:74:67-70.

66. Rugers BL, Morgenstern JP, Garman RD), Bond JI:, Kuo MC'. Recombinant fod d I: expression, purfification, IgL binding and reaction with cat-illergic human Tedls. Mol mmunol 1993:30:559-68:

67. Schou C. Svenden L G, Lowenstem H. Purificalion and chatacteriatton of the major dong allergen, Can fl. (Cin Ixp) Allergy 1901:21:321-8.

68. I. ombardero M, Catrcira J, Dulfort O). Monoclonal antibedy

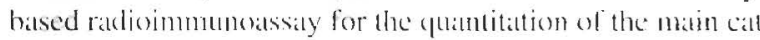
allergen (Fef d I or Cat 1). I Immunol Methods 1988;108:71-6.

69. Schou C. Ilansen GN, Lintuer T. Lewenstein II. Assay for the major dog allergen (anfl: Investigatlon of house dust samples and commercial don extracts. J Allerey ('bin Immunol [(⿻) $1: 88: 847-53$.
70). (iclber LE, Seltzer LH, Bouzoukis JK. Pollart SM, Chizpmitn MI). Platts-Mills TAE. Sensitization and expostute (o) indoor allergens as risk factors for asthma among pallicnts prescuting (o) hospital. Am Rev Respir Dis 1993;147:573-8.

71. Luczynska CM, Li Y, Chapman MD, Platts-Mills TAI: Airborne concentrations and particle size disuribution of allergen derived from domestic cats (Felis domevicus). Am Rev Respir Dis 1990;141:361-7.

72. Wood RA, Eggleston PA, Lind P. et al. Antigenic anilysis of household dust samples. Am Rev Respir Dis 1988:1.37:358-0.3.

73. Luberg RN, Shamie SM, McCullough J, Ownby DR. Ubiquitous presence of cat allergen in ciat-frec buldings: probable dispersal from human chulning. Ann Allergy [6903:70:47]-4.

74. Dybendal T. Ileeland T, Vik H, Apold J, Elsayed S. Dust from carpeted and smooth floors. I. Comparative measurements of! antigenic and allergenic proteins in dust vacuumed from citrpeted and non-carpeted classrooms in Norwegian schools. Clin Exp Allergy 1989;19:217-24.

75. Munir AKM, Einarsson R, Schou C, Dreborg SKG. Allergens in school dust. I. The amoun of the major cat ( $\mathrm{Fel} \mathrm{l}$ I) and dog ( $C$ an $f \mathrm{I}$ ) allergens in dust from Swedish schools is high enough 10 probably cause perennial symptoms in most children with asthma who are sensitized to cat and dog. I Allergy Clin Immunol 1993;91:1067-74.

76. Quirce S, Dimich-Ward H, Ferguson A. ct all. Exposture to l'el $d \mathbf{I}$ and skin reactivity to cat allergen among atsthmillic pitticnts in Canada. J Allergy Clin Immunol (1)4:93:175(A76). (Abst)

77. de Blay F, Chapman MD, Platts-Mills TAE. Airborne cill allergen ( $\mathrm{Fel} d$ l): environmental control wilh the cat in situ. Am Rev Respir Dis 1991; 143:1334-9)

78. Wood RA. Environmental control of amimal allergy. Americam Academy of Allergy and Immunology 1994 Meeting. Workshop 868.

79. Bernton HS, Brown H. Insect allergy: The allergenicity of the excrement of the cockroach. Ann Allergy [970):28:543-7.

80 . Kang B, Vellody D, Homburger $\mathrm{H}$, et al. Cochroalch cause ol asthma. Its specificity and immunologic profile. J Allergy Clin Immunol 1979;63:80-6.

81. Anderson MC, Baer H, Richman P. clal. Immunoelectrophoretic studies of renach allergerns. J Allergy Clin Immunol 1983;7 I: [05. (Abst)

82. Sears MR, Herbison GP, Holdaway MD, Hewill CJ. Lltmnery EM, Silva PA. The relative risks of sensitizillion lo gritss pollen. house dest mite and citt dander in the development of childhoud asthma. ("lin Exp Allerey 1989:19:419-24.

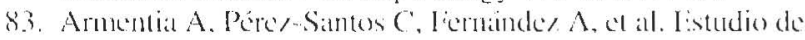
prevalenzia de los acaros productores de alcregrit en la provincia de Vallodolid. Rev Esp Alereol Lmmumol (CIn 1993;8:199-210. 


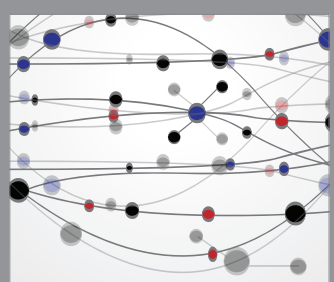

The Scientific World Journal
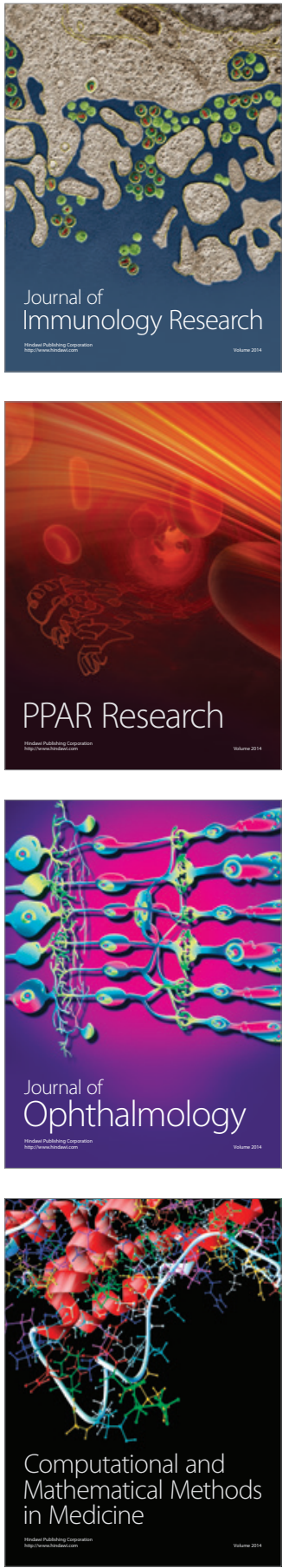

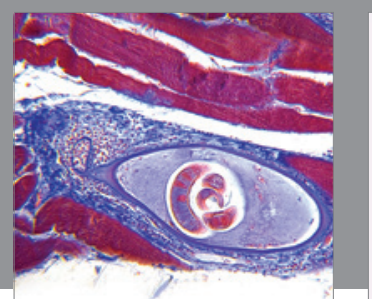

Gastroenterology Research and Practice

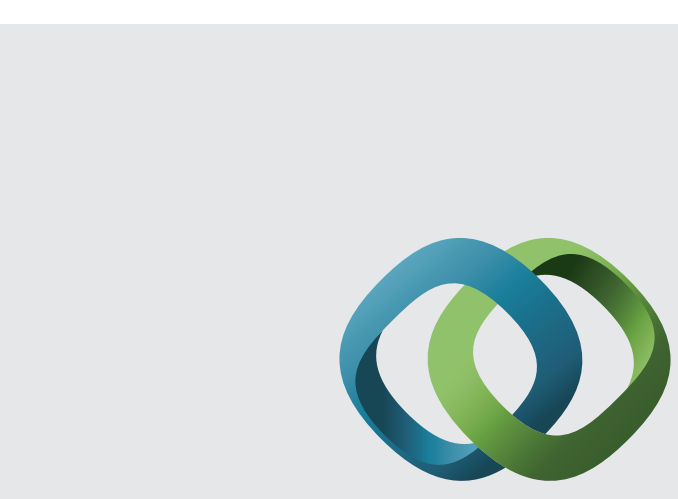

\section{Hindawi}

Submit your manuscripts at

http://www.hindawi.com
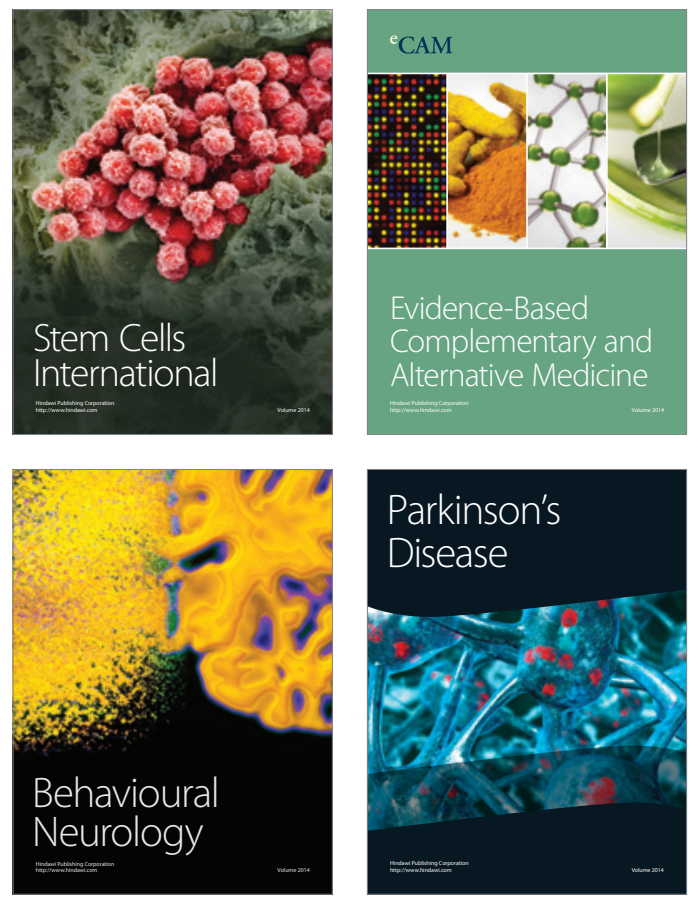
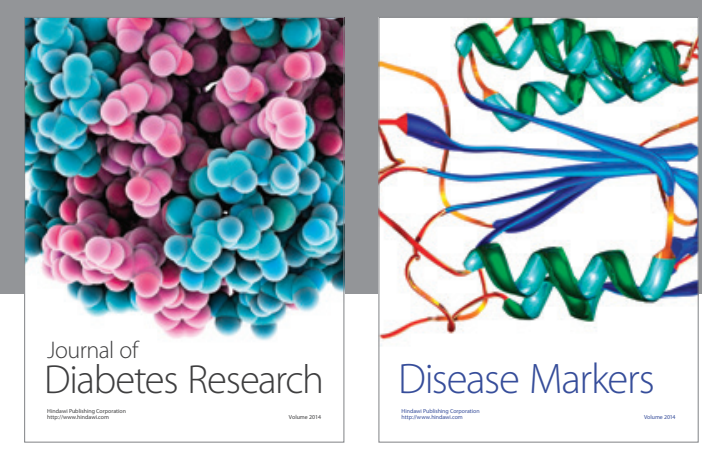

Disease Markers
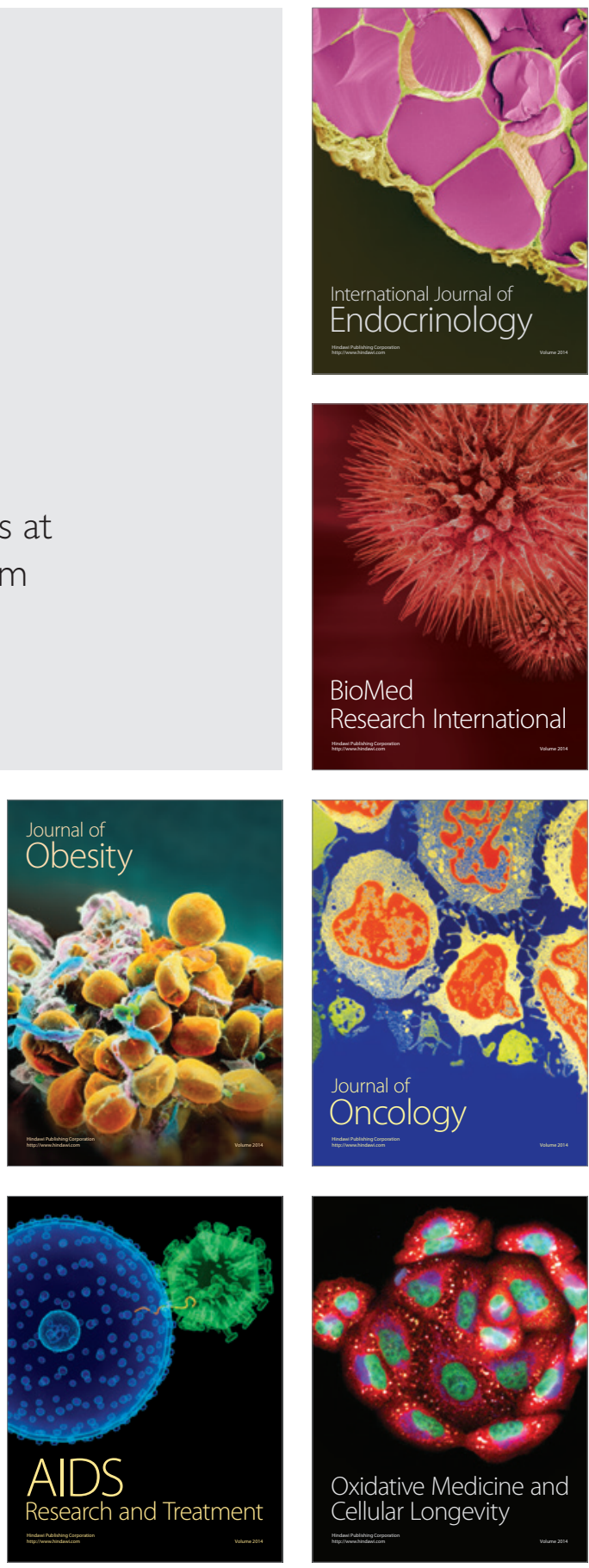